\title{
Bike-sharing: History, Impacts, Models of Provision, and Future
}

\author{
Paul DeMaio \\ MetroBike, LLC
}

\begin{abstract}
This paper discusses the history of bike-sharing from the early 1st generation program to present day 3rd generation programs. Included are a detailed examination of models of provision, with benefits and detriments of each, and a description of capital and operating costs. The paper concludes with a look into the future through discussion about what a 4 th generation bike-sharing program could be.
\end{abstract}

\section{Introduction}

Bike-sharing, or public bicycle programs, have received increasing attention in recent years with initiatives to increase cycle usage, improve the first mile/last mile connection to other modes of transit, and lessen the environmental impacts of our transport activities. Originally a concept from the revolutionary 1960s, bike-sharing's growth had been slow until the development of better methods of tracking bikes with improved technology. This development gave birth to the rapid expansion of bike-sharing programs throughout Europe and now most other continents during this decade.

Since the publication of "Will Smart Bikes Succeed as Public Transportation in the United States?" (DeMaio 2004), much has happened in the nascent field of bike-sharing. While the previous paper discussed the conditions for a successful program, this paper discusses the history of bike-sharing, provides a detailed 
examination of models of provision with benefits and detriments of each, examines capital and operating expenses, and concludes with a look into the future of bike-sharing through a discussion about what a 4th generation bike-sharing program could be.

\section{History of Bike-sharing}

There have been three generations of bike-sharing systems over the past 45 years (DeMaio 2003, 2004). The 1st generation of bike-sharing programs began on July 28, 1965, in Amsterdam with the Witte Fietsen, or White Bikes (Schimmelpennick 2009). Ordinary bikes, painted white, were provided for public use. One could find a bike, ride it to his or her destination, and leave it for the next user. Things did not go as planned, as bikes were thrown into the canals or appropriated for private use. The program collapsed within days.

In 1991, a 2nd generation of bike-sharing program was born in Farsø and Grenå, Denmark, and in 1993 in Nakskov, Denmark (Nielse 1993). These programs were small; Nakskov had 26 bikes at 4 stations. It was not until 1995 that the first large-scale 2nd generation bike-sharing program was launched in Copenhagen as Bycyklen, or City Bikes, with many improvements over the previous generation. The Copenhagen bikes were specially designed for intense utilitarian use with solid rubber tires and wheels with advertising plates, and could be picked up and returned at specific locations throughout the central city with a coin deposit. While more formalized than the previous generation, with stations and a nonprofit organization to operate the program, the bikes still experienced theft due to the anonymity of the user. This gave rise to a new generation of bike-sharing with improved customer tracking.

The first of this new breed of 3rd generation bike-sharing programs was Bikeabout in 1996 at Portsmouth University in England, where students could use a magnetic stripe card to rent a bike (Black and Potter undated). This and the following 3rd generation of bike-sharing systems were smartened with a variety of technological improvements, including electronically-locking racks or bike locks, telecommunication systems, smartcards and fobs, mobile phone access, and on-board computers.

Bike-sharing grew slowly in the following years, with one or two new programs launching annually, such as Rennes' (France) Vélo à la Carte in 1998 and Munich's Call a Bike in 2000, but it was not until 2005 when 3rd generation bike-sharing 
took hold with the launch of Velo'v, with 1,500 bikes in Lyon by JCDecaux (Optimising Bike Sharing in European Cities 2009a, 2009b, 2009c). This was the largest 3rd generation bike-sharing program to date and its impact was noticeable. With 15,000 members and bikes being used an average of 6.5 times each day by late 2005, Lyon's big sister, Paris, took notice (Henley 2005).

Two years later, Paris launched its own bike-sharing program, Vélib', with about 7,000 bikes, which has expanded to 23,600 bikes in the city and suburbs since. This massive undertaking and its better-than-expected success changed the course of bike-sharing history and generated enormous interest in this transit mode from around the world. Outside Europe, bike-sharing finally began to take hold in 2008, with new programs in Brazil, Chile, China, New Zealand, South Korea, Taiwan, and the U.S. Each was the first 3rd generation bike-sharing program for the countries.

By the end of 2007, there were about 603 rd generation programs globally (DeMaio 2007). By the end of 2008, there were about 92 programs (DeMaio 2008a). Currently, there are about 120 programs, as shown in Figure 1, with existing 3rd generation programs shown with a cyclist icon and planned programs shown with a question mark icon (MetroBike 2009).

\section{Bike-sharing's Impacts}

Bike-sharing has had profound affects on creating a larger cycling population, increasing transit use, decreasing greenhouse gases, and improving public health. It has had the affect of raising bike mode share between 1.0 - 1.5 percent in cities with pre-existing low cycling use. Cycle mode share in Barcelona was 0.75 percent in 2005 and increased to 1.76 percent in 2007, the year Bicing was launched (Romero 2008). In Paris, cycle mode share increased from about 1 percent in 2001 to 2.5 percent in 2007, the year Vélib' was launched (Nadal 2007; City of Paris 2007). Cycle facility improvements were made in both cities during these time periods; however, it is difficult to extract the affects the new facilities had on cycle use.

Transit use increases in cities with bike-sharing due to the new bike transit trips, improved connectivity to other modes of transit due to the first mile/last mile solution bike-sharing helps solve, and decreased personal vehicle trips. While bikesharing trips do replace some trips previously made on other modes of transit (50 percent in the case of Velo'v in Lyon), "[ $t$ ] he loss of customers for public transport services is quite low as many users are still holders of a public transport pass" 





(NICHES 2007). The City of Paris reported 50 million trips made by Vélib' in its first two years. In 2008, 28 percent of the survey respondents were less likely to use their personal vehicle; in 2009, this increased to 46 percent. In 2008, 21 percent of survey respondents used Vélib' to reach the subway, train, or bus, and 25 percent used Vélib' on the return trip from other transit modes. In 2009, 28 percent used Vélib' to begin and to end their multi-leg transit trip (City of Paris 2008, 2009).

Many bike-sharing programs take pride in their environmental contribution. Montreal's Bixi proudly states that its program has saved over 3,000,000 pounds of greenhouse gases since inception in May 2009 (Bixi 2009a). Lyon states that its program, which launched in 2005 , has saved the equivalent of $18,600,000$ pounds of $\mathrm{CO} 2$ pollution from the atmosphere (Greater Lyon 2009). The public health benefits of bike-sharing have yet to be analyzed; however, the health benefits of cycling are well-known (Andersen et al. 2000; Cavill and Davis 2006; Shepard 2008).

\section{Models of Provision}

Since bike-sharing's inception, various models of provision have existed (Bührmann 2008). As illustrated in Figure 2, bike-sharing providers have included governments, quasi-governmental transport agencies, universities, non-profits, advertising companies, and for-profits. This section discusses the benefits and detriments of each model.

In the government model, the locality operates the bike-sharing service as it would any other transit service. The government of Burgos, Spain, purchased and operates an off-the-shelf bike-sharing system called Bicibur (Civitas 2009). With this model, the government as operator has greater control over the program. On the other hand, it may not have the experience that existing bike-sharing operators have in managing a program. Also, the government maintains the liability for the program, which can be less desirable from a government's perspective.

The transport agency model has a quasi-governmental organization providing the service. The transport agency's customer is a jurisdiction, region, or nation. Transport agencies, such as Deutsche Bahn of Germany and Stationnement de Montréal, are prime examples. Deutsche Bahn is the national railway provider of Germany and operates a car-sharing and Call a Bike bike-sharing service. Stationnement de Montréal, the parking authority of Montréal, provides "management of municipal paid on-street and off-street parking" and the Bixi bike-sharing 
Journal of Public Transportation, Vol. 12, No. 4, 2009

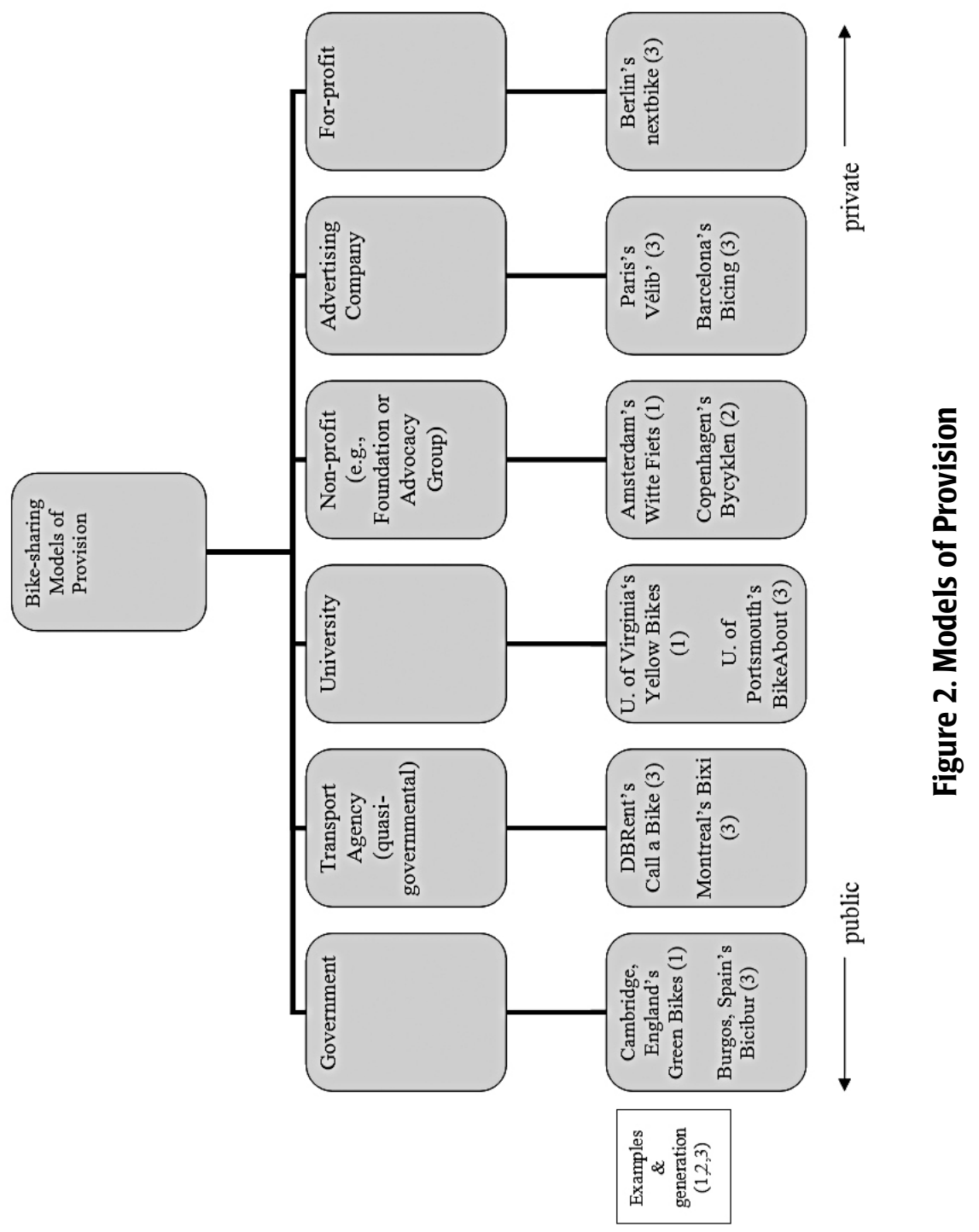


service. Both organizations have gotten into bike-sharing as an extension of their other transport offerings to be a well-rounded mobility provider (Deutsche Bahn 2009; Stationnement de Montréal 2009).

The benefit of the quasi-government transport agency model is that the jurisdiction benefits from the experience and innovation of the bike-sharing service provider, especially in the case of national Deutsche Bahn, without needing to develop the capabilities internally. Additionally, both the jurisdiction and transport agency's top priority is to provide a useful transit service, rather than generating revenues, which is discussed in more detail below as a detriment in the advertising company and for-profit models. A detriment of this model is that, without the locality releasing a tender for the service, a more qualified operator may exist than the transport agency operator.

The university model has the educational institution providing the service, most likely in a campus setting. Examples are the former program at the University of Portsmouth, England, and newer incarnations such as that of St. Xavier University in Chicago (Black and Potter undated; DeMaio 2008b). The benefit of this model is the university can expand its intra-campus transit service without relying on the jurisdiction to offer sufficient bike-sharing service on campus. A detriment is the surrounding jurisdiction potentially would not benefit from the service unless it was opened to the adjacent neighborhoods. Also, if the locality were to use another system, there could be compatibility issues with the university's system.

The non-profit model has an organization which was either expressly created for the operation of the service or one that folds the bike-sharing service into its existing interests. Examples of non-profit programs include the City Bike Foundation of Copenhagen, which operates Bycyklen, and the Nice Ride Minnesota program in Minneapolis (City Bike Foundation of Copenhagen undated; Nice Ride Minnesota 2009). While the non-profit operates the program, it usually receives funding from the jurisdiction for the service it provides to the public in addition to collecting the revenues generated by membership and usage fees and sponsorships (Nice Ride Minnesota 2009). The non-profit model benefits the locality as it removes liability from it and places the liability on the non-profit which has limited funding and is less likely to be sued. A detriment of this model is the non-profit can be reliant on the public sector for a majority of its funding (Nice Ride Minnesota 2009).

With the advertising company model, companies such as JCDecaux, Clear Channel Outdoor, and Cemusa offer a bike-sharing program to a jurisdiction, usually in exchange for the right to use public space to display revenue-generating adver- 
tisements on billboards, bus shelters, and kiosks. The benefit of this model is it can be convenient and cost-effective for local governments that could not afford to provide the bike-sharing service otherwise. To date, this model has been the most popular. A detriment with the advertising company model is the problem of moral hazard. The advertising company usually does not benefit from revenues generated by the system, as the revenues usually go to the jurisdiction, so the advertising company may not have the same incentive to operate the program as if the revenues were directly related to their level of service, regardless of what they agreed to in a service contract. This is highlighted in Paris by the statement by the director general of JCDecaux that its contract with Paris is unsustainable due to the unexpectedly high level of theft and vandalism the program has experienced: "It's simple. All the receipts go to the city. All the expenses are ours" (BBC 2009).

In one case in particular, the advertising company provides the bike-sharing service for a fee and not for an advertising contract. In Barcelona, B:SM (Barcelona de Serveis Municipals), a company owned by the city, has contracted with Clear Channel Outdoor to operate the service (Barcelona de Serveis Municipals undated). This model is more similar to the transport provider model, as the contractor happens to be an advertising company but its advertising services are not used.

In the for-profit model, a private company provides the service with limited or no government involvement. Nextbike is a prime example of this model, with a local business running the service in a locality with the off-the-shelf flexible station system. While similar to the advertising company model, this model differs as there is no on-street advertising contract with the locality and the for-profit keeps all revenues generated. A benefit of this model is that the private sector can start a service as an entrepreneurial activity rather than wait for the public sector to do so. A detriment is that the for-profit may not receive funding assistance for the service as do programs offered under other models. Additionally, if the for-profit uses a fixed, versus flexible, system, they would need to have the locality's support to use public space, unless all stations are on private property.

There is no one ideal model that works best in all jurisdictions. There are factors that affect which models can be used and include the size of the jurisdiction and availability of both bike-sharing systems able to operate in the country and local entrepreneurs to run the program. The size of a jurisdiction is an important factor, as the predominant model of advertising companies providing bike-sharing ser- 
vice tends to be mostly in larger cities where the potential for views of advertising, and therefore advertising revenue, is the greatest.

Demand for bike-sharing has been around longer in Europe than in other continents, and the bike-sharing industry has grown more quickly, which has led to a more rapid growth of programs in European countries. From the continent to the national level, home-grown systems generally dominate in the countries in which they are headquartered. For example, Bicincitta' is headquartered in Italy and has the majority of programs offered there. Both Call a Bike and nextbike are headquartered in Germany and have the majority of programs there. The German government's subsidization of Deutsche Bahn, which offers the Call a Bike service, also has an effect on its growth nationally.

\section{Costs}

The capital and annual operating costs of programs vary greatly, depending on the system, population density, service area, and fleet size. Capital costs include fabrication of the bikes and stations, license or purchase of the back-end system used to operate the equipment, member access cards (if necessary), purchase or rental of maintenance and distribution vehicles, and installation. Clear Channel Outdoor's SmartBike system is estimated to have capital costs of around $\$ 3,600$ per bicycle; JCDecaux's Cyclocity system is estimated at $\$ 4,400$ per bicycle; and Bixi is estimated to be $\$ 3,000$ per bicycle (New York City Department of City Planning 2009). Nice Ride Minnesota is planning to launch in 2010 using Bixi and estimates $\$ 3,200$ per bike (Twin Cities Bike Share 2008).

Operating costs include maintenance, distribution, staff, insurance, office space, storage facilities, website hosting and maintenance, and electricity (if necessary). New York City's analysis of several systems concludes an average operating cost of about $\$ 1,600$ per bicycle (New York City Department of City Planning 2009). Minneapolis expects the same (Twin Cities Bike Share 2008).

\section{Bike-sharing's 4th Generation}

What will the 4th generation of bike-sharing look like? As the 3rd generation of bike-sharing brought about smartening of the concept with smartcards, mobile phones, and kiosks with screens, the hallmark of the 4th generation will be improved efficiency, sustainability, and usability. This is being accomplished by 
improving distribution of bikes, installation, powering of stations, tracking, offering pedalec (pedal assistance) bikes, and new business models.

\section{Improved Distribution}

Distribution of bikes must improve to make the bike-sharing service more efficient and environmentally friendly. Staff moving bikes from areas of high supply/low demand to areas of low supply/high demand is time consuming, expensive, and polluting. Programs will create "push" and "pull" stations which will either encourage trips to leave or arrive, respectively, at these stations based on the demand for bikes. Incentives will include free time, credit, or cash.

Vélib" has made an improvement in this area with the launch of its " $\mathrm{V}+$ " concept, reports Velib et Moi - Le Blog. As it requires more physical effort and time for customers to reach uphill stations, $\mathrm{V}+$ gives an extra 15 minutes to access about 100 of these designated uphill stations. The extra time given has encouraged greater use of these stations. Within the first three months of $V+$ being offered in Summer $2008,314,443$ instances of 15 -minute credits were given. These extra 15-minute bonuses also may be saved up when not used during the trip to the $\mathrm{V}+$ station (Vélib' 2008). Free bike-on-transit capabilities adjacent to specific stations could also assist in pushing bikes uphill where bike-sharers could board another mode of transit. Luud Schimmelpennick, a co-inventor of the bike-sharing concept, reports the operational cost of JCDecaux's distribution of bicycles is about $\$ 3$ each (Schimmelpennick 2009). He believes paying customers for distribution to stations that need more bikes, either through providing a customer credit towards future use or paying the customer outright, would increase distribution efficiency at a fraction of the present cost.

\section{Ease of Installation}

Installing a station takes time and is costly, with removal of asphalt or pavers, undergrounding of the structure and wires, hook-up to a nearby electrical source, and replacement of building materials. Public Bike System has limited this expense with its "technical platform," which is the bike-sharing station's base and houses the wires for its bike dock and pay station. The technical platform is placed on the ground without need for construction, as its weight and minimal bolting to the ground are sufficient to keep it in place (Public Bike System undated) (see Figure $3)$. 


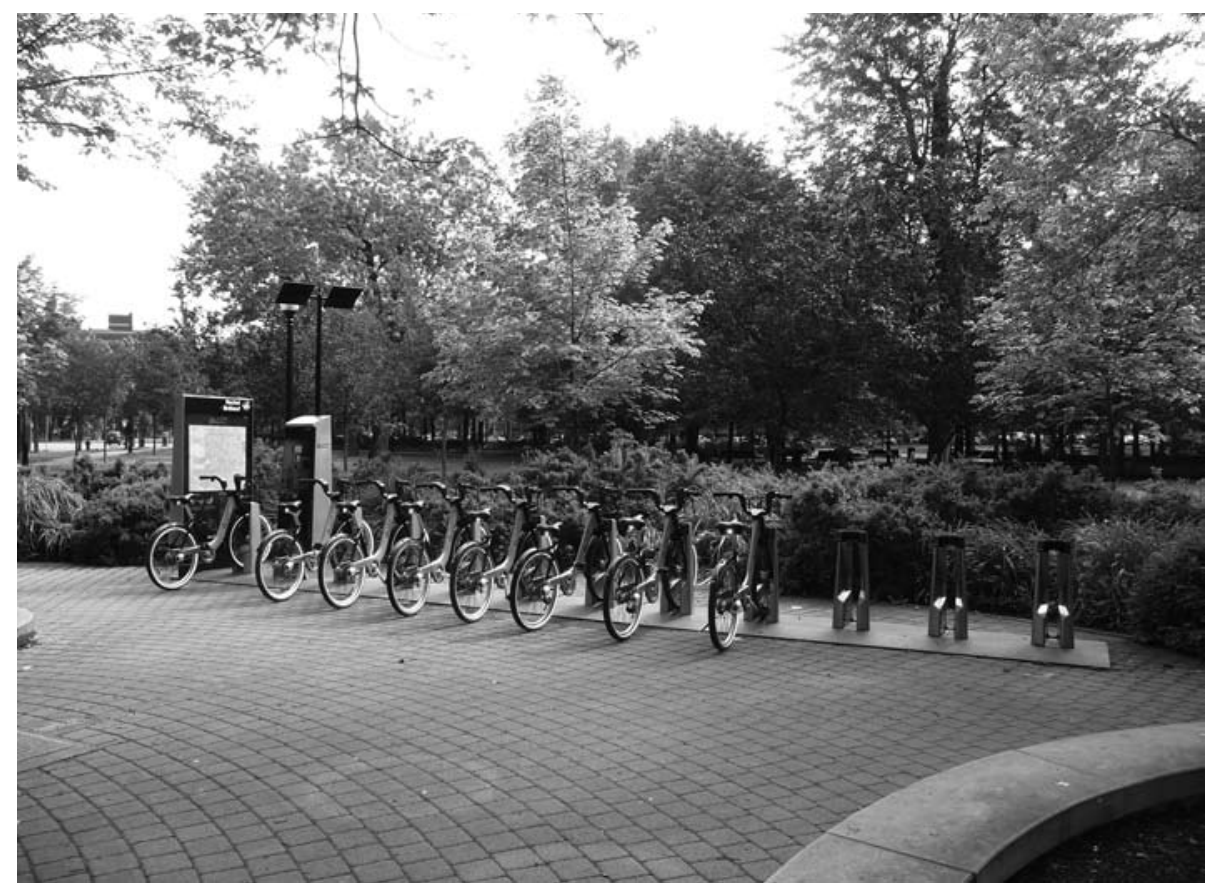

Photo credit: Chris Holben

Figure 3. Bixi Station

\section{Powering Stations}

The powering of stations has generally been with underground wiring to the nearest electrical source. This is expensive, time consuming, and affects where stations may be located. It also prohibits the easy relocation of the station due to the cost. Bixi has incorporated solar panels to remove the need for underground electrification, as have Bicincitta' and B-cycle (Bixi 2009b, Bicincitta' 2009a, B-cycle 2009). Bixi also incorporates rechargeable batteries to provide assistance should there not be enough solar energy for days at a time (Ayotte 2009).

\section{Tracking}

Better tracking of bikes during use with implanted global positioning system (GPS) devices will allow for improved data collection of favorite bike routes and quantification of vehicle miles traveled. Presently, many systems collect "as-the-crow-flies" data, which is a straight line between a customer's origin and destination but may not accurately show the true distance of the bike trip. Also, GPS could allow for improved collection of stolen bikes. 


\section{Pedal Assistance}

Not everyone has the leg strength to ride a bike, especially in hilly areas. Pedelec, or electric pedal assistance bikes, will allow those who would not otherwise be physically able, to give bike-sharing a try. Just as buses have added kneeling and wheelchair features to open themselves up to passengers with disabilities, electric pedal assistance moves bike-sharing to a wider audience. A bike-sharing fleet need not be composed entirely of pedalec bikes, but rather a percentage of vehicles for this purpose to lower the barrier for a portion of the population. Systems that use pedalecs are in Genoa and Monaco, both programs of Bicincitta' (Bicincitta' 2009b, Avenir du Vehicule Electrique Mediterraneen 2008).

\section{Business Model}

As the demand for bike-sharing increases, the models of provision will continue to experience growth. New bike-sharing system vendors have sprung up in the industry and created their own systems, such as nextbike, Bixi, Veloway, and Smoove. Many of these systems have no outdoor advertising component but rather can be purchased by a local operator. These systems are allowing jurisdictions and universities with populations too small to make outdoor advertising profitable or where advertising on public space is prohibited to consider launching their own bike-sharing services.

\section{Conclusion}

The future of bike-sharing is clear: there will be a lot more of it. Gilles Vesco, Vice President of Greater Lyon, quotes his mayor when saying, "There are two types of mayors in the world: those who have bike-sharing and those who want bikesharing." This certainly seems to be the case as each bike-sharing program creates more interest in this form of transit-call it a virtuous cycle. As the price of fuel rises, traffic congestion worsens, populations grow, and a greater world-wide consciousness arises around climate change, it will be necessary for leaders around the world to find new modes of transport and better adapt existing modes to move people in more environmentally sound, efficient, and economically feasible ways. Bike-sharing is evolving rapidly to fit the needs of the 21 st century.

\section{References}

Andersen, L., P. Schnohr, M. Schroll, and H.O. Hein. 2000. All-cause mortality associated with physical activity during leisure time, work, sports, and cycling to 
work. Archives of Internal Medicine. 160:1621-1628. http://archinte.ama-ssn. org/cgi/content/full/160/11/1621/.

Avenir du Vehicule Electrique Mediterraneen. 2008. February 28. http://translate. google.com/translate?prev=_t $\& \mathrm{hl}=$ en $\& \mathrm{ie}=\mathrm{UTF}-8 \& \mathrm{u}=\mathrm{http} \% 3 \mathrm{~A} \% 2 \mathrm{~F} \% 2 \mathrm{Fwww}$. avem.fr\%2Factualite-monaco-des-velos-electriques-en-libre-service-386. html\&sl=fr\&tl=en\&history_state0/.

Ayotte, A. 2009. Conversation with author. July 13.

Barcelona de Serveis Municipals. undated. BSM Organización. http://www.bsmsa. es/index.php?id $=10 \& L=1 /$.

BBC. 2009. Thefts puncture Paris bike scheme. February 10. http://news.bbc. co.uk/2/hi/europe/7881079.stm/.

B-cycle. 2009. What is B-cycle? http://www.bcycle.com/.

Bicincitta'. 2009a. Gallery. http://bicincitta.com/gallery.asp/.

Bicincitta'. 2009b. Genoa. http://74.125.113.132/translate_c?hl=en\&sl=it\&u= http://www.bicincitta.com/citta_v3.asp\%3Fid\%3D33\&prev=/search\%3Fq \%3D\%252Bmobike\%2B\%252Bgenova\%26hl\%3Den\%26client\%3Dfirefoxa\%26rls\%3Dorg.mozilla:en-US:official\%26hs\%3DX41\%26sa\%3DG\&rurl=trans late.google.com\&usg=ALkJrhijAARamP_sUSmk_aUVqkTXn000lw/.

Black, C., and S. Potter. Undated. Portsmouth bikeabout: A smart-card bike club scheme. http://www.metrobike.net/index.php?s=file_download\&id=11/.

Bixi. 2009a. Overview. http://www.bixisystem.com/bixi_system/overview/.

Bixi. 2009b. Information. http://montreal.bixi.com/home/home-info/.

Bührmann. 2008. Bicycles as public-individual transport - European developments. 18. http://www.metrobike.net/index.php?s=file_download\&id=2/.

Cavill, N., and A. Davis. 2006. Cycling and Health. 9-43. http://www.networks.nhs. uk/uploads/07/11/cycling_and_health.pdf/.

City Bike Foundation of Copenhagen. undated. Bycyklen København. http://www. bycyklen.dk/.

City of Paris. 2007. Le Bilan des Deplacements en 2007 a Paris. La Mairie de Paris, L'Observatorie de Deplacements, Paris, France. http://www.paris.fr/portail/ 
deplacements/Portal.lut?page_id=7627\&document_type_id=4\&document_ id=26324\&portlet_id=17647\&multileveldocument_sheet_id=11982/.

City of Paris. 2008. La lettre Vélib'. May. 10. http://velib.centraldoc.com/ newsletter/10_aujourd_hui_nous_vous_connaissons_mieux/.

City of Paris. 2009. La lettre Vélib'. June. 22. http://velib.centraldoc.com/ newsletter/22_bientot_2_ans_d_utilisation_votre_regard_sur_le_service/.

Civitas. 2009. City bike scheme in Burgos. http://www.civitas-initiative.org/measure_sheet.phtml?lan=en\&id=302/.

DeMaio, P. 2003. Smart bikes: Public transportation for the 21st century. Transportation Quarterly 57(1): 9-11.

DeMaio, P. 2004. Will smart bikes succeed as public transportation in the United States? Journal of Public Transportation 7(2): 1-15.

DeMaio, P. 2007. What a year for bike-sharing. December 30. http://bike-sharing. blogspot.com/2007/12/what-year-for-bike-sharing.html/.

DeMaio, Paul. 2008a. Bike-sharing Wrap-up for 2008. December 31. http://bikesharing.blogspot.com/2008/12/bike-sharing-wrap-up-for-2008.html/.

DeMaio, P. 2008b. University bike-sharing's time has come. The Bike-sharing Blog. October 26. http://bike-sharing.blogspot.com/2008/10/university-bike-sharings-time-has-come.html/.

Deutsche Bahn. 2009. DB Fuhrpark. http://www.dbfuhrparkservice.de/site/ dbfuhrpark/de/anschlussmobilitaet/anschlussmobilitaet.html/.

Greater Lyon. 2009. Velo'v la newsletter. March. 37. http://www.velov.grandlyon. com/Newsletter-Velo-v-numero-37.134.0.html/.

Henley, J. 2005. Rentabike moves up a gear from curiosity to runaway success. The Guardian. August 12. http://www.guardian.co.uk/world/2005/aug/12/ france.jonhenley/.

MetroBike. 2009. The Bike-sharing world map. http://maps.google.com/maps/ $\mathrm{ms}$ ?ie $=$ UTF8\&hl $=$ en $\&$ om $=1 \& \mathrm{msa}=0 \& \mathrm{msid}=104227318304000014160.00043$ d80f9456b3416ced \& $\|=43.580391,-42.890625 \& \mathrm{spn}=143.80149,154.6875 \& \mathrm{z}=1$ \&source $=$ embed $/$. 
Nadal, L. 2007. Bike sharing wweeps Paris off its feet. Sustainable Transport. 19. 8 - 12. http://www.itdp.org/documents/st_magazine/ITDP-ST_Magazine-19. pdf/.

New York City Department of City Planning. 2009. Bike-share opportunities in New York City. 84. http://www.nyc.gov/html/dcp/pdf/transportation/ bike_share_complete.pdf/.

NICHES. 2007. Public bicycles. p. 5. http://ange.archangelis.com/typo3/niches/ fileadmin/New_folder/Deliverables/D4.3b_5.8_b_PolicyNotes/14397_pn4_ public_bikes_ok_low.pdf/.

Nice Ride Minnesota. 2008. Twin Cities bike share project business plan. 38-9. http://www.niceridemn.com/downloads/doc_plan.php/. Nice Ride Minnesota. 2009. Nice Ride Minnesota. http://www.niceridemn.com/.

Nielse, B. H. 1993. The Bicycle in Denmark: Present Use and Future Potential. Danish Ministry of Transport. 52.

Optimising Bike Sharing in European Cities. 2009a. France. FR_Rennes_Old System tab. http://www.obisproject.com/palio/html.run?_Instance=obis\&_ PagelD=4\&_LngID=21\&_CatID=722\&pic=4\&_CheckSum=1012982978/.

Optimising Bike Sharing in European Cities. 2009b. Germany. DE_Berlin tab. http://www.obisproject.com/palio/html.run?_Instance=obis\&_PagelD $=4 \&$ _ LnglD $=21 \& \_C a t \mid D=722 \& p i c=4 \& \_C h e c k S u m=1012982978 /$.

Optimising Bike Sharing in European Cities. 2009c. France. FR_Lyon tab. http:// www.obisproject.com/palio/html.run?_Instance=obis\&_PagelD $=4 \&$ _ LnglD=21\&_CatID=722\&pic=4\&_CheckSum=1012982978/.

Romero, C. 2008. SpiCycles in Barcelona. Presented to Chamber of Commerce and Industry, December 19, in Bucharest, Romania. 31. http://spicycles.velo.info/ Portals/0/FinalReports/Barcelona_Final_Report.ppt/.

Schimmelpennick, L. 2009. Conversation with author. March 5.

Shepard, R. 2008. Is Active Commuting the answer to population health? Sports Medicine. 39(9): 751-758.

Stationnement de Montréal. 2009. Stationnement de Montréal. http://www.statdemtl.qc.ca/index.php?page_id=42\&lang=en/. 
Stationnement de Montréal. undated. Public Bike System. 15. http://www.metrobike.net/index.php?s=file_download\&id=13/.

Twin Cities Bike Share. 2008. Non-profit business plan for Twin Cities bike share system. December 3. 36 - 44. http://www.niceridemn.com/downloads/ doc_plan.php/.

Vélib'. 2008. Velib et Moi - Le Blog. October 2. http://blog.velib.paris.fr/blog/ reportages/triomphe-des-bonus-v-vous-ameliorez-tous-les-jours-le-servicevelib/.

\section{About the Author}

PaUl DeMalo (paul@metrobike.net) has been involved in bike-sharing since 1996 as an undergraduate student in Copenhagen, Denmark. In 2005, he created MetroBike, LLC to focus on bike-sharing and bike transportation planning. He has a Bachelor of City Planning from the University of Virginia School of Architecture and a Master of Transportation Policy, Operations, and Logistics from the George Mason University School of Public Policy. He is also the author of The Bike-sharing Blog (bike-sharing.blogspot.com), an international news resource about the field. 